\author{
St ud a P hiloso phic a \\ Wrat is lavi e n s i \\ vol. XV, fasc. $4(2020)$
}

https://doi.org/10.19195/1895-8001.15.4.10

\begin{abstract}
MIESZKO WANDOWICZ*
ORCID: 0000-0002-4582-3081

Uniwersytet Wrocławski
\end{abstract}

\title{
Podręcznik myślenia
}

Juliusz Domański, Wykłady o humanizmie, Biblioteka kwartalnika „Kronos”, Fundacja Augusta hr. Cieszkowskiego, Warszawa 2020, s. 862.

Pytanie, czym jest filozofia, najczęściej kojarzone dziś ze znanym esejem Martina Heideggera ${ }^{1}$, ale przyjmujące także inne oblicza i prowadzace do innych odpowiedzi, prawdopodobnie będzie zadawane tak długo, jak tylko pojęcie, którego dotyczy, pozostanie w użyciu przynajmniej części osób zainteresowanych myśleniem. Na kartach Wykładów o humanizmie Juliusza Domańskiego można znaleźć między innymi rozważania na temat znaczenia kryjącego się za owym słowem; być może znaleźć je w nie mniejszym stopniu aniżeli te odnoszące się do samego humanizmu, również spotykającego się z wielością rozumień. Albowiem ten obszerny tom, liczący mniej więcej 650 stron tekstu głównego oraz około 200 poświęconych na indeksy, a przede wszystkim na aneks z greckimi i łacińskimi cytatami wzbogaconymi o tłumaczenia, można potraktować jako przejaw pewnego metafilozoficznego wyboru, jakkolwiek pozbawionego radykalizmu.

Juliusz Domański to jedna z najważniejszych postaci zajmujących się we współczesnej Polsce umiłowaniem mądrości. Filolog klasyczny i historyk filozofii, wybitny starożytnik i mediewista, jest autorem między innymi takich książek, jak Metamorfozy pojęcia filozofii, Poczatki humanizmu, „Scholastyczne” i „humanistyczne" pojęcie filozofii czy Philosophica, paraphilosophica, metaphilosophica. Studia i szkice z dziejów myśli dawnej² — jeśli spośród ponad 200 publikacji w róż-

\footnotetext{
* Autor jest stypendystą Fundacji Augusta hr. Cieszkowskiego (2019).

1 M. Heidegger, Co to jest filozofia?, tłum. S. Blandzi, [w:] Heidegger dzisiaj, P. Marciszuk, C. Wodziński (red.), Warszawa 1991.

2 J. Domański, Metamorfozy pojęcia filozofii, tłum. Z. Mroczkowska, M. Bujko, Warszawa 1996; J. Domański, Początki humanizmu, Wrocław 1982; idem, „Scholastyczne” i „humanistyczne” pojęcie
} 
nych językach ograniczyć się do książek. To również znawca i tłumacz Erazma z Rotterdamu ${ }^{3}$. Dlatego też trudno się dziwić, że poddany redakcji i opublikowany został jego pięcioletni cykl wykładów wygłoszonych w latach dziewięćdziesiątych w Instytucie Filologii Klasycznej Uniwersytetu Warszawskiego — wykładów rozpoczętych od Platona, a zakończonych na słynnym niderlandzkim myślicielu. Jeśli zaś chodzi o podejście Domańskiego do dyscypliny, jaką się zajmuje, dość napisać, że na podobieństwo między jego a swoją twórczością zwrócił uwagę Pierre Hadot, autor rozpraw zatytułowanych Ćwiczenia duchowe i filozofia starożytna oraz Czym jest filozofia starożytna? — prac, które spopularyzowały pojmowanie umiłowania mądrości jako ä $\sigma x \eta \sigma \iota \varsigma^{4}$. Spośród współczesnych wolno, jak się zdaje, dodać do tych dwóch jeszcze Karla Alberta, twórcę takich dzieł, jak Studia o historii filozofii tudzież O Platońskim pojęciu filozofii ${ }^{5}$. Spojrzenia owej trójki pod niektórymi względami od siebie odbiegają, można jednak ich uznać za czołowych reprezentantów asketycznego rozumienia filozofii. Warto też zatrzymać się na moment przy prezentowanym przez Domańskiego rozróżnieniu na „scholastyczność"

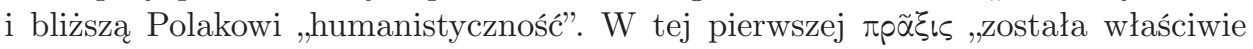
z pojęcia filozofii wyeliminowana"6, wszelako badania teoretyczne starały się dotyczyć nieomal każdego aspektu wiedzy. Ta druga, przeciwnie, skupiała się na „etyce realizowanej”, rezygnując z tego, co dla dobrego życia nieprzydatne: „podczas gdy scholastycy byli maksymalistami filozoficznymi, humanistów wypadnie uznać za filozoficznych minimalistów"8.

Tekst główny składa się z pięciu długich części, każdej reprezentującej jeden rok cyklu, a także z zakończenia-podsumowania, będącego przedrukiem późniejszego, jako że przedstawionego już w tym stuleciu, artykułu pod tytułem Kilka myśli o swoistości $i$ nieredukowalności człowieka, czyli o humanizmie i filozofii. Treść i forma zostały zmienione prawdopodobnie w niewielkim stopniu, jakkolwiek styl świadczy o spisaniu wykładów jeszcze przed ich wygłoszeniem.

Część pierwsza, pod tytułem Starożytne przesłanki pojęcia humanizmu, ma charakter zdecydowanie filologiczny. Ważne są w niej dociekania etymologiczne dotyczące samego humanizmu. Oto powstały w XV wieku łaciński neologizm humanista nie odnosił się co prawda do niczego poza uniwersyteckim rzemiosłem, ale

filozofi, Kęty 2005; idem, Philosophica, paraphilosophica, metaphilosophica. Studia i szkice z dziejów myśli dawnej, Kraków 2008.

3 Por. np. J. Domański, Erazm i filozofia. Studium o koncepcji filozofii Erazma z Rotterdamu, Wrocław 1973.

${ }^{4}$ P. Hadot, Ćwiczenia duchowe i filozofia starożytna, tłum. P. Domański, W. Klenczon, Warszawa 2019 (książka publikowana wcześniej pod tytułem Filozofia jako ćwiczenie duchowe); P. Hadot, Czym jest filozofia starożytna?, tłum. P. Domański, Warszawa 2000. W przetłumaczonej na polski przedmowie do francuskiego wydania Metamorfoz Domańskiego Hadot napisał: „Nasze badania rozwijały się w sposób całkowicie niezależny. Ale nasze drogi, choć wyszły z różnych punktów, ostatecznie zbiegły się ze sobą" (J. Domański, Metamorfozy, s. VII).

5 K. Albert, Studium o historii filozofii, tłum. B. Baran, J. Marzęcki, Warszawa 2006; K. Albert, O Platońskim pojęciu filozofii, tłum. J. Drewnowski, Warszawa 1991.

6 J. Domański, „Scholastyczne” $i$,humanistyczne” pojęcie filozofii, s. 122.

7 Ibidem, s. 211.

8 Ibidem. 
pochodził od starszego słowa humanitas, które Geliusz w Nocach attyckich kojarzył z grecką $\pi \alpha \iota \varepsilon \varepsilon i \alpha$ : „wykształceniem i przyswojeniem sobie szlachetnych umiejętności” (s. 26), a w którym Cyceron widział „wewnętrzną kulturę człowieka” (s. 38). Autor, unaoczniając greckie inspiracje Rzymian, zauważa przy tym wyraźną odmienność „między postawą filozoficzną, jaką jest postawa Platona, a postawą humanistyczną, którą — avant la lettre niejako — zdaje się reprezentować Cyceron" (s. 50-51) (nie bez inspiracji znanym konkurentem Platona - Izokratesem). Do tego nawiążę jeszcze pod koniec tekstu. Tu warto zaznaczyć, że więcej humanizmu znalazł Domański u Arystotelesa, czy to za sprawą postawienia przezeń w Poetyce poezji, atakowanej w dialogu Politeia, ponad badaniami historycznymi — ze względu na dokonywany w niej przez artystę wybór tudzież katartyczną funkcję jej oraz tragedii - czy to przez podkreślenie w Polityce nieustannego podejmowania decyzji, za którymi idzie ápetń bądź jej brak, a zatem trwałej wolności człowieka.

Część druga — Starożytność chrześcijańska i twórcy średniowiecza — rozpoczyna się od istotnego rozróżnienia między tradycją a recepcją. „Tradere to raczej »przekazywać bezpośrednio « niż »pośrednio «", podczas gdy recepcja ,implikuje lub przynajmniej dopuszcza nieciągłość i pośredniość" (s. 162), co pozwala na pewien dystans do rozważanych kwestii; dystans, którego brakowało średniowiecznym scholastykom, a którego nauczyli się odrodzeniowi humaniści. To zresztą na co Domański zwrócił uwagę - mimo diametralnych różnic kulturowych relacja podobna do tej, która zaszła między myślicielami greckimi, nade wszystko sprzed epoki hellenistycznej, i Rzymianami; przez tych drugich grecka tradycja zaczęła być bowiem recypowana. To nie znaczy, że przez wszystkich: koncepcje związane

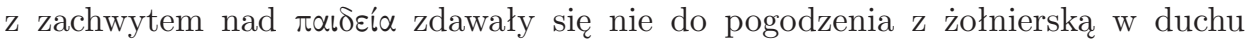
Romanitas, co zostało przedstawione w Wykładach z ukłonem w stronę Rudolfa Pfeiffera i jego pracy sprzed nieomal wieku. Jako sprawa odrębna jawi się, aczkolwiek wciąż związane zarówno z tradycją, jak i recepcją, przysposobienie (adaptacja) kultury greckiej przez wczesne chrześcijaństwo. Mowa o odrzuceniu pogańskich: teatru, poezji i nieledwie wszystkiego poza wyselekcjonowanymi aspektami filozofii, z których w Nowym Testamencie korzystał nade wszystko Paweł z Tarsu, później zaś apologeci, również uznając je za przydatne narzędzie. Osobny rozdział poświęcony został św. Augustynowi i jego — by za autorem użyć anachronicznego słowa ${ }^{9}$ - teodycei utkwionej w dialogu De ordine, gdzie wywyższał nie tylko Boga, jak pierwsi obrońcy chrześcijaństwa, ale i samo umiłowanie mądrości. Zestawiony jednak w nieoczywisty sposób z Platonem i Cyceronem poziomem humanistyczności — w ujęciu Domańskiego — bliższy wydaje się temu pierwszemu: radykalny, wrogi poezji, domagający się podporządkowania ratio i dialektyce.

Część trzecia, zatytułowana Scholastyka i późne średniowiecze, to już odejście od antyku na tyle, na ile to możliwe w pracy o takiej tematyce. Była więc scholastyka, podążając ścieżką Augustyna i Boecjusza, sposobem racjonalnego myślenia podporządkowanego „wyższemu autorytetowi boskiemu i niższemu autorytetowi ludzkiemu" (s. 281). Ten racjonalizm: specyficznego typu scjentyzm, oparty na

${ }^{9}$ Który to anachronizm, jak i pojawiające się w tomie anachroniczne odniesienia do humanizmu i humanistyczności, został przez autora zaznaczony. 
ówczesnym odczytaniu Arystotelesowego rozumienia ध̇ंı znalazł Domański jeszcze w Parmenidejskim fragmencie B3 ${ }^{10}$, łączył się, co jasne, z charakterystyczną strukturą powstających tekstów ${ }^{11}$, ale też z wrogością wobec pisarstwa artystycznego; obfitością za to komentarzy do dzieł uznanych za klasyczne. Warto przyjrzeć się, choćby było to głównie uporządkowaniem posiadanej wiedzy, zawartym w tomie i popartym uwagami filologicznymi rozważaniom o ,autorytetach” i odmiennych rodzajach ,autorów”: „skrybach”, ,kompilatorach”, ,komentatorach", a także o zgoła innym niż współczesne pojmowaniu „oryginalności”: nie brak w nich pouczających, niechby historycznie, odwołań — od św. Bonawentury po Warrona. Jeśli zaś chodzi o walkę o czystość łaciny, i tutaj można się wiele dowiedzieć z krótkiego fragmentu o piętnastowiecznym humaniście Lorenzo Valli.

Jednakże w trzeciej części książki ważniejszy bodaj, a z pewnością dłuższy jest krok następny, ciągnący się właściwie jeszcze przez część czwartą, skupioną na mniejszej, także czasowo, przestrzeni, a zatytułowaną Humanizm włoski XV wieku. To wykłady o tym, co pierwotnie było wprawdzie oddalone od głównego nurtu, ale zaistniało i pozostawiło po sobie ślady. Mowa właśnie o walce: walce z „unaukowieniem chrześcijaństwa". Domański wyróżnił dwie drogi, którymi podążali niezadowoleni ze scholastycznych metod myśliciele. Jedna to próba powrotu do nieusystematyzowanych jeszcze źródeł wiary, „do autentyczności i czystości”, drugą był właśnie średniowieczny humanizm. Sporo tu ciekawych odniesień, uzupełnionych przetłumaczonymi cytatami, dla przykładu tymi z Gesta Salvatoris Szymona z Cascii (w książce: Simone de Cassia) — jak opisał dzieło polski filozof: „manifestu antyscholastycznego" - atakującego scholastykę „nie tylko za jej poszczególne treści materialne, rzeczowe, nie za konkretne twierdzenia, ale za jej ducha i za jej formę" (s. 324). Za to, że scholastycy, „nie mając czystej i prostej oraz koniecznej wiedzy Pisma Świętego, starają się ją zdobyć, dodając do niej sylogizmy" (s. 329). Średniowieczny humanizm, co bodaj nie zaskakuje, został więc w tomie przedstawiony raczej jako obrona chrześcijaństwa niż podważający je nurt, obrona podszyta między innymi filologicznymi argumentami. Zgoła zresztą, co ciekawe, różniącymi się od siebie: nadmiar chwytów retorycznych wedle autora Gesta Salvatoris i brak kunsztu retorycznego wedle „nawróconego scholastyka” Gerta Groota, osobliwej postaci, której również poświęcił Domański kilka stron.

Groot jednak, w odróżnieniu od Szymona z Cascii, nie był Włochem, wyłamując się z przywołanej przez Petrarkę - w potocznej, lecz całkiem uzasadnionej opinii pierwszego humanistę renesansowego — zasady, mówiącej, że „nie trzeba szukać oratorów i poetów poza Italią" (s. 451). Ten ostatni zresztą, jak zauważył

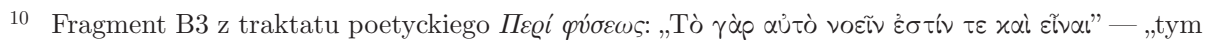
samym bowiem pojmowanie jest oraz bycie” (M. Wesoły, Parmenides z Elei — physikos, „Przegląd Filozoficzny" 2 (2001), s. 59-85). Mowa tu w najczęściej bodaj przyjmowanej, zaproponowanej przez Domańskiego, interpretacji o „tożsamości bytu i myślenia” (s. 281).

11 Ogólnie przyjęta forma została w książce szczegółowo opisana, w dużej mierze na sztandarowym przykładzie św. Tomasza z Akwinu. Warto tu, być może, przywołać refleksję na temat specyfiki naukowego żargonu: „dysproporcji pomiędzy ubóstwem i monotonią słów zwykłych [...] a bogactwem i nawet pewną wybujałością słownictwa intelektualnego" (s. 311). Zdaje się, że taka tendencja pojawia się niekiedy także we współczesnych tekstach.

Studia Philosophica Wratislaviensia, vol. XV, fasc. 4 (2020)

(C) for this edition by CNS 
Domański, mógł mieć na Groota bezpośredni wpływ: obaj przebywali w tym samym czasie w Pradze. Wpływ ten nie został udowodniony, ale jeśli przypuszczenie jest słuszne, to potwierdza przeświadczenie o pierwszeństwie Półwyspu Apenińskiego nad innymi regionami Europy w rozwoju charakterystycznego dla odrodzenia sposobu myślenia. Jakie były owego myślenia podstawy? $\mathrm{Na}$ to pytanie odpowiadał autor tomu między innymi w rozdziale na temat studia humanitatis i Leonarda Bruniego. Składnikami renesansowego wykształcenia były „gramatyka, retoryka, historia, poetyka i filozofia moralna" (s. 473); przy czym pierwsza z nich — zgodnie z rozumieniem starożytnym — to umiejętność nie tylko języko-, ale i literaturoznawcza. Do takiego modelu gramatyki starali się humaniści wrócić. Nie mniej istotna była inna dziedzina, której wedle Bruniego, będącego tylko jednym z licznych w książce przykładów, należało uczyć się z pomocą dzieł klasycznych - retoryka. „Humaniści cenili uczucia bardziej niż budowana na racjonalizmie filozofii scholastyka, liczyli się bowiem z bardziej wielostronnie rozumianymi potrzebami człowieka, przede wszystkim zaś z jego potrzebą działania, która od sfery uczuć (pragnień, lęków itp.) oddzielić się nie dawała" (s. 489). Właśnie retoryka pozwalała na owe uczucia wpływać.

Tak wszelako jak w Studiach Karla Alberta rozważania o filozofii Platona prowadziły do skupienia się na mistyce Mistrza Eckharta, a to nawet jeśli Niemiec poświęcił potem jeszcze rozdział na czasy trwające od Kartezjusza po współczesność, tak jako cel intelektualnej drogi zaprezentowanej przez Juliusza Domańskiego jawi się przedstawienie postaci oraz przesłania Erazma z Rotterdamu, pokazanego głównie na przykładzie trzech jego dzieł. Dlatego też część piąta: Erazm $i$ humanizm, skoncentrowana jest na osobie „kończącej pewne trendy rozwojowe” (s. 541), trendy rozpoczęte ponad stulecie wcześniej w Italii. Odnosząc się do tych stronic, należy zaznaczyć, że mimo iż już przed laty Domański, a dawniej i później wielu innych, pisał o filozofii Rotterdamczyka, podkreślone w Wykładach zostało, że Erazm „, jako humanista, i jako teolog był przede wszystkim” filologiem (s. 565), podobnie jak — w pewnym uproszczeniu — odrodzeniowi myśliciele w ogóle. Z tego względu w dużej mierze starożytnej literatury i kultury dotyczył tytuł jednego z rozdziałów umieszczonych przez niego w dialogu Antibarbari ${ }^{12}$ : „Absurdem jest przyganiać czemuś nie z innej przyczyny, jak tylko dlatego, że wynalezione przez pogan". Mowa zatem o rozumieniu przedchrześcijańskich tekstów: filozofii czy poezji, a także sztuk wyzwolonych jako przejawu Bożej opatrzności, który trzeba tylko odpowiednio wykorzystać, aby przy pomocy nabytych dzięki nim wiedzy i praktycznych umiejętności mieć w sobie więcej tak godności, jak i godziwości.

Wyktady, jakkolwiek będąc dziełem tyleż historycznym, ile filologicznym, sac zarazem — jak już wspominałem — wyraźnie naznaczone pewnym podejściem do filozofii i ogólniej: kultury europejskiej, a wraz z nim zawierają mniej lub bardziej intuicyjne w tym kontekście interpretacje albo pozwalające na niezgodę rozstrzygnięcia. Tak jest między innymi w tych miejscach, w których zajął się Domański

12 Pozostałe dwie główne przywołane pozycje to Enchiridion, apologetyczny, a jednocześnie zwalczający sztuczną religijność, oraz wstęp do Nowego Testamentu, zatytułowany Ratio seu methodus verae theologiae. 
humanistycznością Platona. Autor wyraził wątpliwości, czy autora dialogów wolno humanistą nazwać mimo skupienia się przez ich głównego bohatera - Sokratesa — na tym, co w życiu godziwe. Wyraził je, niejako zbliżając się wręcz do rozpowszechnionej współcześnie Popperowskiej interpretacji Politei, a to w takim sensie, w jakim dostrzegł u Platona postulat nie-ludzkiego ograniczenia wolności poprzez rezygnację z uczuć i sporej części sztuki na rzecz idącej jedynym akceptowalnym tropem rozumności. Można tu zadać pytanie: czy to, mimo wszystko, nie nazbyt dosłowna lektura dialogu? Jego twórca był przecież skłonny do estetyzacji i niejednoznaczności; a słynna przestroga z Phaidrosa, niezależnie od tego, jak odczytywać szczegóły, co do sedna pozostaje aktualna. Wypada jednak pamiętać, że polski filozof nie przedstawił swojej wizji stanowczo, ale zaznaczył, iż to koncepcja do rozważenia. Przywołał zresztą odmienną interpretację umieszczoną w „pięknym wykładzie o humanizmie i teologii" Wernera Jaegera ${ }^{13}$, a pisząc o humanizmie u Stagiryty, podkreślił, że wizje Platona i Arystotelesa nie są tak odległe, jak mogłoby się wydawać. Wyktady o humanizmie Juliusza Domańskiego nie są bowiem książką, z którą w każdym szczególe z zasady należy się zgadzać. To raczej podręcznik myślenia, oparty na imponującej, ściśle opisanej wiedzy historycznej, ale niestanowiący sprzeciwu wobec innych opinii niż autorskie — wszak jedną z podstaw humanizmu jest uznanie możliwości wyciągania różnych wniosków. To przy tym, jak się zdaje, tom tego formatu co Ćwiczenia duchowe i filozofia starożytna Hadota czy niewiele od Wykładów dłuższe Studia o historii filozofii Alberta bądź Paideia Jaegera, przeznaczony dla podobnej grupy odbiorców. Tej, która ufa definicji zaproponowanej przez Izydora z Sewilli, że umiłowanie mądrości „to poznanie rzeczy boskich i ludzkich połączone ze staraniem o dobre życie" (s. 543), a nawet idącemu dalej osądowi Jakuba z Gostynina: „Człowiek mający wiedzę rzeczy boskich i ludzkich, a nie żyjący godziwie, nie zasługuje na miano filozofa" (s. 650).

13 ,Świat Platona, powiada, podobnie zresztą jak świat Homera, może być scharakteryzowany jako zarazem antropocentryczny i teocentryczny. Człowiek i jego życie znajdują się na pierwszym planie myśli zarówno Platona, jak i Sokratesa czy Arystotelesa i w tym sensie jest ona antropocentryczna; ale Bóg jest w centrum tego ludzkiego świata" (s. 658). Por. W. Jaeger, Humanizm i teologia, tłum. S. Zalewski, Warszawa 1957; idem, Paideia. Formowanie człowieka greckiego, tłum. M. Plezia, H. Bednarek, Warszawa 2001.

Studia Philosophica Wratislaviensia, vol. XV, fasc. 4 (2020)

(C) for this edition by CNS 